\title{
Acetylcholine Synthesis and Release Is Enhanced by Dibutyryl Cyclic AMP in a Neuronal Cell Line Derived from Mouse Septum
}

\author{
Jan Krzysztof Blusztajn, ${ }^{1,2}$ Amy Venturini, ${ }^{1}$ Darrell A. Jackson, ${ }^{1,3}$ Henry J. Lee, ${ }^{4}$ and Bruce H. Wainer ${ }^{4,5}$ \\ Departments of ${ }^{1}$ Pathology and ${ }^{2}$ Psychiatry, Boston University School of Medicine, Boston, Massachusetts 02118 , \\ 3Department of Brain and Cognitive Sciences, Massachusetts Institute of Technology, Cambridge, Massachusetts 02139 , \\ and Departments of ${ }^{4}$ Pharmacological and Physiological Sciences and ${ }^{5}$ Pathology, The University of Chicago, Chicago, \\ Illinois 60637
}

\begin{abstract}
Cholinergic properties of the SN56.B5.G4 cell line derived from the fusion of neurons of the mouse postnatal day 21 septum and the murine neuroblastoma cell line N18TG2 were investigated and correlated with morphological differentiation. In basal serum-containing growth medium, few cells developed neurites. Neurite extension occurred in cells grown for $2 \mathrm{~d}$ with forskolin or dibutyryl CAMP (dbcAMP) but not with butyrate. In cells treated with these compounds, the activity of ChAT and ACh content were two- to threefold higher relative to controls. The cells synthesized ACh from choline taken up by the sodium-dependent high-affinity transport. Forskolin-, dbcAMP-, and butyrate-treated cells (but not the controls) were capable of spontaneous and depolarization-evoked ACh release. The results indicate that the morphological and the neurochemical aspects of SN56.B5.G4 cell differentiation are independently regulated.
\end{abstract}

The process of synthesis, storage, and release of $\mathrm{ACh}$ requires the expression of several specialized enzymatic systems. In the initial step of $\mathrm{ACh}$ synthesis, choline is taken up from the extracellular space by a sodium-dependent high-affinity uptake system (SDHACU). SDHACU is present predominantly in the nerve terminals of cholinergic cells (Suszkiw and Pilar, 1976). Since a large proportion of choline taken up by this process is converted to ACh, it has been postulated that SDHACU may be coupled to ChAT, which catalyzes ACh synthesis utilizing acetylCoA as the acetate donor. AcetylCoA generation and turnover may be regulated in a specific fashion in cholinergic cells (Szutowicz et al., 1983). The ACh may then be taken up into the secretory vesicles by a specific carrier (Parsons et al., 1987). The synthesis and assembly of the vesicular membrane are likely to require enzymes specific for cholinergic neurons. The molecular mechanisms that mediate ACh release into the synapse are poorly understood. In order to investigate the regulation of these and other properties of brain cholinergic neurons, we have developed cell lines derived from fusion of the murine neuroblastoma cells, N18TG2, which lack cholinergic markers, with postnatal day 21 mouse brain septal neurons. At this age, the septal cells do not divide and their ACh synthesis is similar to that of the adult (Shelton et al., 1979). We also expect that these

Received May 3, 1991; revised Oct. 8, 1991; accepted Oct. 10, 1991.

This study was supported by NSF BNS8808942, MH46095, and NS25787, and the Center for Alternatives to Animal Testing grants.

Correspondence should be addressed to Jan Krzysztof Blusztajn, Room M1009, Boston University School of Medicine, 85 East Newton Street, Boston, MA 02118.

Copyright (C) 1992 Society for Neuroscience $0270-6474 / 92 / 120793-07 \$ 05.00 / 0$ hybrid cell lines should prove useful in studying the mechanisms of action of a variety of growth factors that enhance the cholinergic phenotype. The list of such molecules includes NGF (Hefti et al., 1985), basic fibroblast growth factor (Vaca et al., 1989), ciliary neurotrophic factor (Saadat et al., 1989), ChAT development factor (McManaman et al., 1988), cholinergic differentiation factor (Fukada, 1985) recently shown to be identical to leukemia inhibitory factor (Yamamori et al., 1989), membrane-derived factor (Adler et al., 1989), target-derived neuronal cholinergic differentiation factor (Rao and Landis, 1990), interleukin 3 (IL-3) (Kamegai et al., 1990b), and granulocytemacrophage colony-stimulating factor (GM-CSF) (Kamegai et al., 1990a). Cholinergic differentiation may also be enhanced by pharmacologic agents. Among them, the analogs of the second messenger cAMP have been shown to increase the activity of ChAT in neuron-like cell lines including the murine neuroblastoma lines (Prasad and Kumar, 1974), rat pheochromocytoma, PC1 2 cells (Green and Tischler, 1976), and the neuroblastoma $\times$ glioma hybrid NG108-15 cells (Daniels and Hamprecht, 1974). In this report, we describe some attributes of a murine septal cell line, SN56.B5.G4, and show that these properties are similar to those characteristic of septal neurons. The cholinergic features of SN 56.B5.G4 cells are enhanced by treatment with a cAMP analog, $\mathrm{N}^{6}, \mathrm{O}^{2}$-dibutyryl-adenosine $3^{\prime}, 5^{\prime}$-cyclic monophosphate (dbcAMP). In addition, our data indicate that the enhancement of the cholinergic phenotype is regulated independently from the neuron-like morphological differentiation of these cells.

\section{Materials and Methods}

\section{Materials}

Cell culture plastic was from Costar Corp. (Cambridge, MA) or Becton Dickinson Labware (Lincoln Park, NJ). Media and sera were from GIBCO Laboratories Inc. (Grand Island, NY). Chemicals were from Sigma Chemical Co. (St. Louis, MO). ${ }^{14} \mathrm{C}$-Methyl-choline chloride $(55 \mathrm{Ci} / \mathrm{mol})$ and ${ }^{3} \mathrm{H}$-acetyl-CoA $(15 \mathrm{Ci} / \mathrm{mmol})$ were from ICN Biomedicals, Inc. (Irvine, CA).

\section{Cell culture}

The SN56.B5.G4 cells were created by fusing N18TG2 neuroblastoma cells with murine (strain C57BL/6) neurons from postnatal day 21 septa (Hammond et al., 1990; Lee et al., 1990). The SN56.B5.G4 and the parent neuroblastoma $\mathrm{N} 18 \mathrm{TG} 2$ cells were maintained at $37^{\circ} \mathrm{C}$ in an atmosphere of $95 \%$ air, $5 \% \mathrm{CO}_{2}$ in Dulbecco's Modified Eagle's Medium (DMEM) containing 10\% fetal bovine serum (FBS), and $50 \mu \mathrm{g} / \mathrm{ml}$ gentamicin. Media in stock flasks were changed every $2-3 \mathrm{~d}$. The cells were subcultured by mechanically removing them from the substratum with squirts of fresh media. Cells of up to passage 25 were used. When cells 
were grown in the presence of various pharmacologic agents, the media were changed daily.

\section{ACh content}

In order to measure the cellular ACh content, the cells were incubated for $1 \mathrm{hr}$ in their growth media containing various pharmacologic agents (see figure captions and table notes) and $15 \mu \mathrm{M}$ neostigmine. The cells were then washed twice with ice-cold Hank's balanced salt solution containing $15 \mu \mathrm{M}$ neostigmine and extracted with methanol, and their ACh was determined as described below.

\section{${ }^{14} \mathrm{C}-\mathrm{ACh}$ accumulation}

To measure ${ }^{14} \mathrm{C}$-ACh accumulation, the cells were incubated at $37^{\circ} \mathrm{C}$ in a physiological salt solution (containing, in mM: $\mathrm{NaCl}, 135 ; \mathrm{KCl}, 5$; $\mathrm{CaCl}_{2}, 1 ; \mathrm{MgCl}_{2}, 0.75$; glucose, 5; eserine, 0.015 ; HEPES, $10 ; \mathrm{pH}, 7.4$ ) in the presence of ${ }^{14} \mathrm{C}$-choline. The time periods of incubations and ${ }^{14} \mathrm{C}$ choline concentrations are given in figure captions. The ${ }^{14} \mathrm{C}-\mathrm{ACh}$ accumulated by the cells was extracted and purified by HPLC, and its radioactivity was determined.

\section{${ }^{14} \mathrm{C}-\mathrm{ACh}$ release}

To measure ${ }^{14} \mathrm{C}-\mathrm{ACh}$ release, the cells were incubated for $180 \mathrm{~min}$ at $37^{\circ} \mathrm{C}$ in $\mathrm{L}-15$ medium containing $10 \mu \mathrm{M}{ }^{14} \mathrm{C}$-choline and $15 \mu \mathrm{M}$ eserine. The cells were washed with L-15 medium (as above) and then incubated for an additional $30 \mathrm{~min}$ in a physiological salt solution (containing, in mM: $\mathrm{NaCl}, 135 ; \mathrm{CaCl}_{2}, 1 ; \mathrm{MgCl}_{2}, 0.75 ;$ glucose, 5; eserine, 0.015; HEPES, $10 ; \mathrm{pH}, 7.4$ ) and either $5 \mathrm{~mm}$ (control) or $40 \mathrm{~mm}$ potassium chloride (the concentration of sodium chloride was reduced to $100 \mathrm{~mm}$ ). The media were collected, and ${ }^{14} \mathrm{C}$-ACh released from the cells was purified by HPLC and its radioactivity determined.

\section{Analytical methods}

Extraction of cells. After the desired treatment, the media were removed from the culture dishes and methanol was added $(1 \mathrm{ml}$ and $1.4 \mathrm{ml}$ per $35 \mathrm{~mm}$ and $60 \mathrm{~mm}$ diameter dish, respectively). The cells were scraped off the dishes and the methanolic suspensions transferred to polypropylene tubes. Two volumes of chloroform were then added, and the tubes were vortexed. The extracts were then washed with a volume of water equal to the initial amount of methanol, and centrifuged to separate the two phases. The water-soluble metabolites of choline (choline, ACh, phosphocholine, glycerophosphocholine, cytidinediphosphocholine) were in the aqueous (upper) phase, and the lipids were in the organic (lower) phase. Proteins collected at the interface and could be used for protein assay. The phases were collected and dried under a vacuum.

Purification of water-soluble choline metabolites. The water-soluble choline metabolites were purified by a modification of our HPLC. method (Liscovitch et al., 1985) on a normal phase column $10 \mathrm{~cm}$ long, 4.6 $\mathrm{mm}$ internal diameter containing $3 \mu \mathrm{m}$ silica particles (Dynamax, Rainin Instruments Co., Woburn, $\mathbf{M} \Lambda$ ), using a linear gradient elution based on increasing polarity and ionic strength, with two mobile phases: $A$, containing acetonitrile/water/ethanol/acetic acid/1.0 M ammonium acetate/0.1 M sodium phosphate monobasic $(800: 127: 68: 2: 3: 10, \mathrm{v} / \mathrm{v})$, and B (same components, 400:400:68:53:79:10, v/v). The mobile phase was varied from 0 to $100 \%$ of $B$ with a slope of $5 \% / \mathrm{min}$, starting 6 min after sample injection. At a flow rate of $1.5 \mathrm{ml} / \mathrm{min}$, typical retention times for the following compounds were (in $\mathrm{min}$ ) $\mathrm{ACh}, 8$; choline, 9; glycerophosphocholine, 12; cytidinediphosphocholine, 14; and phosphocholine, 17 . In experiments utilizing ${ }^{14} \mathrm{C}$-choline, the radioactivities associated with these peaks were quantitated by an on-line monitor using a solid-phase scintillation flow cell (Berthold, model LB 507 A).

$A C h$ measurements. ACh was determined by HPLC with an enzymatic reactor containing acetylcholinesterase and choline oxidase and an clectrochemical detector using a commercial kit (Bioanalytical Systems Inc., West Lafayette, IN) based on the method of Potter et al. (1983).

\section{Quantitative analyses}

Choline acetyltransferase activity was determined in cell homogenates by the method of Fonnum (1975). Protein was determined using bicinchoninic acid by the method of Smith et al. (1985) and DNA by the method of Labarca and Paigen (1980).

\section{Statistics}

Significance of difference between means was determined by $t$ test or analysis of variance and Tukey test as appropriate. Hyperbolic regression was performed with the aid of SYSTAT version 5 software (Systat Inc., Evanston, IL) on a Macintosh IIci personal computer.

\section{Results}

\section{Morphological differentiation of SN56.B5.G4 cells}

When maintained in basal growth medium (DMEM/10\% FBS), SN56.B5.G4 cells were polygonal and extended few neurites (Fig. $1 A$ ). Addition of $1 \mathrm{~mm}$ dbcAMP (Fig. $1 B$ ), a cell-permeant analog of cAMP, or of $10 \mu \mathrm{M}$ forskolin, an activator of adenylate cyclase, to the medium slowed down cell division and caused neurite outgrowth. Because the dbcAMP molecule can be hydrolyzed to liberate free butyric acid, the effect of butyrate (2 mM) on the morphology of SN56.B5.G4 cells was also investigated. Under those conditions, the cells were rounder than controls and no neurite extension was observed (Fig. 1C).

\section{Stimulation of $A C h$ synthesis and neurite extension are regulated independently in SN56.B5.G4 cells}

In order to investigate whether there was a correlation between neurite extension and $\mathrm{ACh}$ synthesis and content, the cells were grown for $2 \mathrm{~d}$ in the basal medium or in the presence of $1 \mathrm{~mm}$ dbcAMP, $10 \mu \mathrm{M}$ forskolin, or $2 \mathrm{~mm}$ butyrate. ChAT activity as well as the ACh content were determined. The specific activity of ChAT was elevated approximately 2.7-3-fold by each of the treatments (Fig. 2). The cells grown in the basal medium contained $0.88 \pm 0.19 \mathrm{nmol} / \mathrm{mg}$ protein (mean $\pm \mathrm{SD}$ ) of $\mathrm{ACh}$. The ACh content was elevated by approximately $70-85 \%$ by each of the treatments (Fig. 2). However, cells treated with butyrate did not extend neurites, indicating that morphological differentiation did not correlate with elevations in ChAT activity and/ or ACh levels. Because elevated ChAT activity and ACh levels were observed both in neurite-bearing (i.e., dbcAMP- and forskolin-treated) as well as in neurite-free (i.e., butyrate-treated) cells, it is concluded that the enhancement of the cholinergic phenotype is regulated independently from neurite extension.

\section{ACh synthesis in SN56.B5.G4 cells is enhanced by dbcAMP in a time- and dose-dependent manner}

The dbcAMP-treated cells accumulated more ${ }^{14} \mathrm{C}-\mathrm{ACh}$ when incubated with ${ }^{14} \mathrm{C}$-choline than did the controls. The effect of dbcAMP was both time and dose dependent. The maximal enhancement ( $275 \%$ of control) of ${ }^{14} \mathrm{C}$-ACh accumulation was observed after $2 \mathrm{~d}$ of exposure to $1 \mathrm{~mm}$ dbcAMP (Fig. 3). The ${ }^{14} \mathrm{C}$-ACh accumulation was enhanced by dbcAMP in a saturable manner, reaching a maximum of 3.4-fold at $5 \mathrm{~mm}$ dbcAMP after a $2 \mathrm{~d}$ treatment (Fig. 4). The concentration of dbcAMP that caused half-maximal stimulation of ${ }^{14} \mathrm{C}$-ACh accumulation was $1.3 \mathrm{~mm}$ (Fig. 4). No ${ }^{14} \mathrm{C}$-ACh was observed in the N18TG2 parent neuroblastoma cells grown in the basal medium or treated with $1 \mathrm{~mm} \mathrm{dbcAMP}$ for $48 \mathrm{hr}$ (data not shown).

\section{SN56.B5.G4 septal cells release ACh upon depolarization}

We investigated whether ACh could be released upon depolarization by elevating extracellular potassium concentrations. The cells were prelabeled with $10 \mu \mathrm{M}{ }^{14} \mathrm{C}$-choline and then incubated for an additional $30 \mathrm{~min}$ in a physiological salt solution containing either 5 or $40 \mathrm{mM} \mathrm{K}^{+}$, and ${ }^{14} \mathrm{C}$-ACh released from the cells was purified by HPLC and its radioactivity determined. The results, expressed as dpm/ $\mu \mathrm{g}$ of DNA, are shown in Figure 

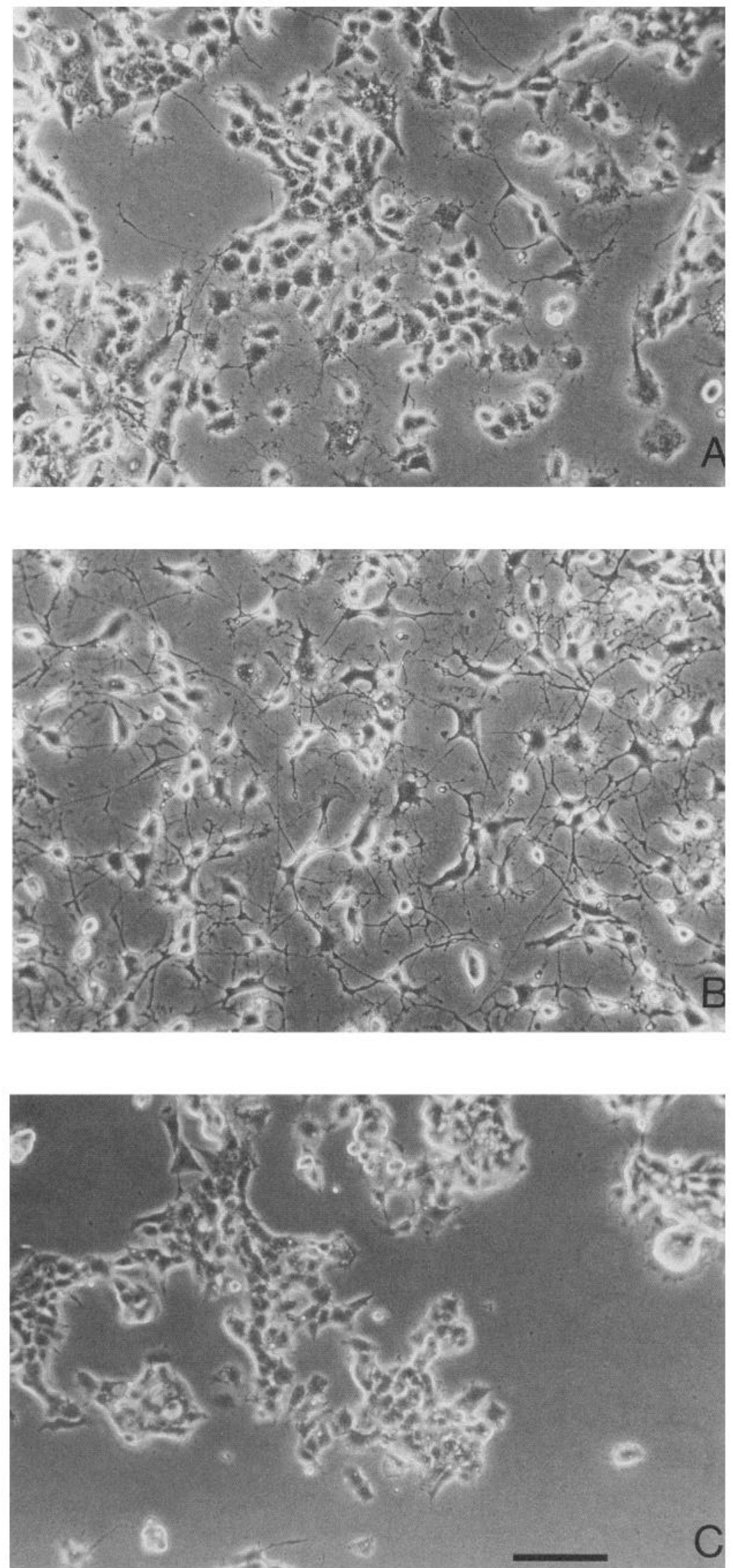

Figure 1. Morphological differentiation of SN56.B5.G4 cells. Phase-contrast photomicrographs of SN56.B5.G4 cells grown as described in Materials and Methods in $35 \mathrm{~mm}$ diameter culture dishes containing $2 \mathrm{ml}$ of the basal medium (DMEM/10\% FBS) $(A)$ supplemented with $1 \mathrm{mM}$ dbcAMP $(B)$ or $2 \mathrm{~mm}$ butyrate $(C)$. The medium was changed daily, and the cells were photographed after $2 \mathrm{~d}$ of treatment. Scale bar, $100 \mu \mathrm{m}$ for $A-C$. 


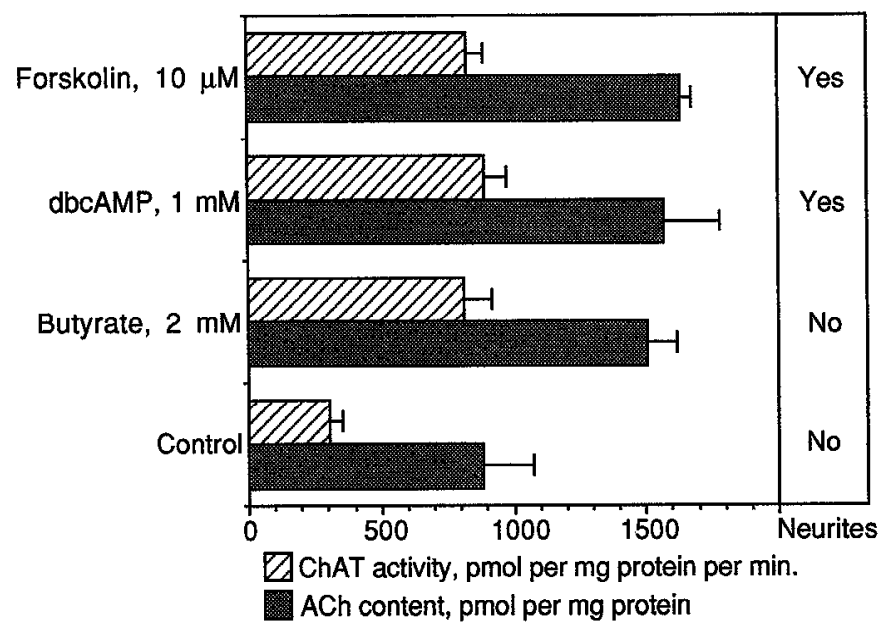

Figure 2. The morphological and neurochemical differentiation of SN56.B5.G4 cells are independently regulated. The cells were grown for $2 \mathrm{~d}$ in the presence of the agents indicated. Neurite formation was assessed by an observer who was not aware of the nature of the treatments. The growth media were removed and the cells were incubated at $37^{\circ} \mathrm{C}$ for an additional $1 \mathrm{hr}$ period in fresh growth media containing the agents indicated and $15 \mu \mathrm{M}$ neostigmine. The media were removed, and the cells were washed twice with Hank's balanced salt solution containing $15 \mu \mathrm{M}$ neostigmine prior to the extraction of $\mathrm{ACh}$. $\mathrm{ACh}$ was determined by HPLC. ChAT activity was measured in cell homogenates. The results are reported as means \pm SD. One-way ANOVA followed by a Tukey test was used to determine the statistical significance of differences between groups. ChAT activity and ACh content was significantly different $(p<0.005)$ in control cells relative to each of the treatment groups. No other statistically significant differences were found.

5 and are taken from an experiment in which ACh could be detected in cells grown in the basal medium. In the majority of experiments, ACh release was undetectable, indicating that the SN56.B5.G4 cells were incapable of ACh release when grown in their basal medium. Therefore, we tested the hypothesis that the differentiated cells would release ACh. When the SN56.B5.G4 cells were grown in the presence of $1 \mathrm{mM}$ dbcAMP, $10 \mu \mathrm{M}$ forskolin, or $2 \mathrm{mM}$ butyrate for $48 \mathrm{hr}$, ACh release was reliably observed and depolarization led to elevation of $\mathrm{ACh}$ release (Fig. 5). The spontaneous and the depolarization-evoked $\mathrm{ACh}$ release occurred both in neurite-free (butyrate-treated) and neurite-bearing (dbcAMP- or forskolin-treated) cells.

\section{SN56.B5.G4 cells synthesize ACh from choline taken up by a} sodium-dependent high-affinity transport

In order to determine whether SN56.B5.G4 cells express SDHA$\mathrm{CU}$, the apparent affinity for choline of the choline uptake and of the ACh synthetic process was studied by incubating the cells for $10 \mathrm{~min}$ in a medium of varying ${ }^{14} \mathrm{C}$-choline concentration. The radioactivity of the total intracellular ${ }^{14} \mathrm{C}$-choline was measured, and ${ }^{14} \mathrm{C}-\mathrm{ACh}$ was purified and its radioactivity determined. The total uptake of choline could be resolved into a saturable process exhibiting an apparent $K_{m}$ of $5.3 \mu \mathrm{M}$ and a linear component, perhaps reflecting diffusion (data not shown). The process of ${ }^{14} \mathrm{C}$ - $\mathrm{ACh}$ accumulation was saturable with choline and could be best described by a rectangular hyperbola (Fig. 6). The apparent affinity for choline of ${ }^{14} \mathrm{C}$-ACh accumulation was determined by least-squarcs hyperbolic regression. The apparent $K_{m}$ was $4.6 \mu \mathrm{M}$ and the apparent $V_{\max }$ was 16.5 pmol per dish per $10 \mathrm{~min}$. The $K_{m}$ value is thus in the range characteristic of SDHACU. No ${ }^{14} \mathrm{C}$-ACh was observed in similar experiments

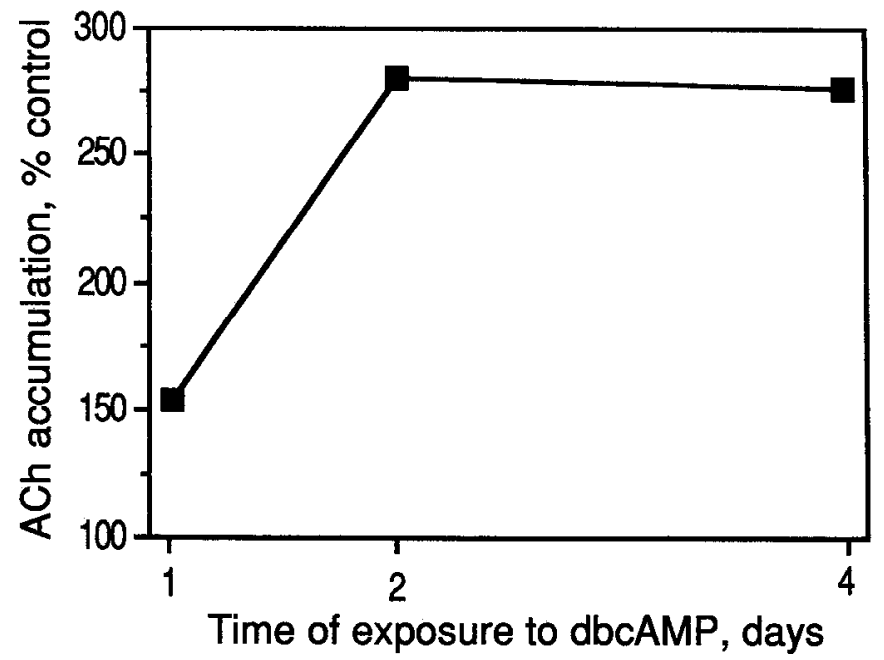

Figure 3. Time course of stimulation of ${ }^{14} \mathrm{C}-\mathrm{ACh}$ accumulation by dbcAMP in SN56.B5.G4 cells. The cells were grown for various periods of time in the presence of $1 \mathrm{~mm}$ dbcAMP with daily medium change. ${ }^{14} \mathrm{C}$-ACh accumulation was determined in cells incubated for $10 \mathrm{~min}$ at $37^{\circ} \mathrm{C}$ in the presence of $2.5 \mu \mathrm{M}{ }^{14} \mathrm{C}$-choline. ${ }^{14} \mathrm{C}$-ACh was extracted and purified by HPLC, and its radioactivity was determined.

performed on the N18TG2 parent neuroblastoma cells (data not shown). When the cells were incubated in medium in which sodium was replaced by lithium, accumulation of ${ }^{14} \mathrm{C}$ - $\mathrm{ACh}$ from $1 \mu \mathrm{M}{ }^{14} \mathrm{C}$-choline was diminished to $29 \%$ of control (Table 1). This inhibition was less pronounced when ${ }^{14} \mathrm{C}-\mathrm{ACh}$ accumulation was measured in the presence of $5 \mu \mathrm{M}$ extracellular ${ }^{14} \mathrm{C}$ choline. These data show that when extracellular choline concentration is low $(1 \mu \mathrm{M})$, most (70\%) of the ACh in SN56.B5.G4 cells is synthesized from choline taken up by an SDHACU. At higher choline concentrations, the low-affinity process (or diffusion) also provides choline for ACh synthesis. Similar results have been obtained by others using primary cultures of rat septum [i.e., 50-70\% of $\mathrm{ACh}$ was derived from choline taken up by the high-affinity transport (Keller et al., 1987; Bostwick et al., 1989)]. These data suggest that SN56.B5.G4 cells express high-affinity sodium-dependent uptake for choline and that their $\mathrm{ACh}$ is synthesized from choline taken up by this system.

\section{Discussion}

The phenotypic properties of any hybrid cell line will depend on the contribution of each of the parents. The SN56.B5.G4 cells exhibit several features of the cholinergic phenotype that presumably were contributed by the septal neuronal parent. This assertion is supported by our inability to detect ChAT activity or ${ }^{14} \mathrm{C}$-ACh accumulation in the $\mathrm{N} 18 \mathrm{TG} 2$ parent neuroblastoma cells grown either in basal or in dbcAMP-supplemented medium (data not shown). Thus, it is likely that the cholinergic properties as well as their enhancement by the differentiating protocols reported here are due to the expression of septal neuronal genes (although the possibility that activation of the N18TG2 genes occurred cannot be excluded).

The SN56.B5.G4 cells have been selected from other septal lines based on ChAT activity. However, in order to serve as a useful model of brain cholinergic neurons, it was important to establish whether these cells exhibit other features of the cholinergic phenotype. The ACh content of these cells is similar to NS20 neuroblastoma cells ( $2 \mathrm{nmol} / \mathrm{mg}$ protein) (Kato et al., 


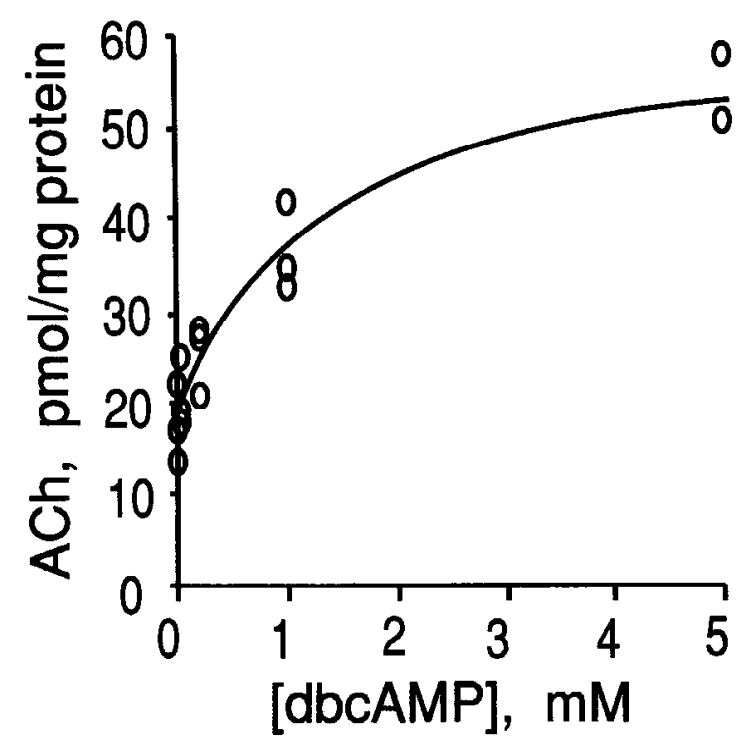

Figure 4. ${ }^{14} \mathrm{C}-\mathrm{ACh}$ accumulation in SN56.B5.G4 cells is enhanced by dbcAMP in a dose-dependent manner. The cells were grown for $2 \mathrm{~d}$ in the presence of dbcAMP at various concentrations. ${ }^{14} \mathrm{C}$-ACh accumulation was determined in cells incubated for $10 \mathrm{~min}$ at $37^{\circ} \mathrm{C}$ in the presence of $2.5 \mu \mathrm{M}{ }^{14} \mathrm{C}$-choline. ${ }^{14} \mathrm{C}$-ACh was extracted and purified by HPLC, and its radioactivity was determined. The results were calculated using the specific radioactivity of the ${ }^{14} \mathrm{C}$-choline precursor. The data are results from triplicate determinations. A rectangular hyperbola was fit to the data according to the Michaelis equation plus a constant reflecting the fact that untreated cells contained $\mathrm{ACh} . \mathrm{EC}_{50}=1.3 \mathrm{mM}$. Correlation coefficient of this regression was $r^{2}=0.991$.

1977) but lower than that of the human neuroblastoma LA-N-2 cells grown in a similar medium (approximately $10 \mathrm{nmol} / \mathrm{mg}$ protein) (Richardson et al., 1989). By comparison, ACh content of rat striatum is $0.3 \mathrm{nmol} / \mathrm{mg}$ protein (Cohen and Wurtman, 1976) and that of purely cholinergic synaptosomes from Torpedo electric organ is $130 \mathrm{nmol} / \mathrm{mg}$ protein (Morel et al., 1977).

SDHACU has been used extensively in the studies of cholinergic function as a marker of cholinergic nerve terminals (Blusztajn and Wurtman, 1983, for a review). The observation that ACh synthesized by SN56.B5.G4 cells is produced from choline taken up by SDHACU (Fig. 6) set these cells apart from a variety of ChAT-expressing cell lines including NS20 neuroblastoma (Lanks et al., 1974), NG108-15 neuroblastoma $\times$ glioma (McGee, 1980), PC12 pheochromocytoma (Melega and Howard, 1981), and LA-N-2 neuroblastoma (Richardson et al., 1989), all of which synthesize $\mathrm{ACh}$ from choline taken up by the ubiquitous low-affinity carrier. Thus, the SN56.B5.G4 cells resemble septal neurons, which maintain their ability to express SDHACU in organotypic cultures (Keller et al., 1987).

Another feature of cholinergic neurons is the release of $\mathrm{ACh}$ upon depolarization. SN56.B5.G4 cells grown in basal medium (DMEM $/ 10 \%$ FBS) failed to release ACh reliably. Therefore, we hypothesized that a differentiating treatment might be found that would allow these cells to release the neurotransmitter. We used initially a cAMP analog, dbcAMP, because of extensive literature showing that a variety of neuronal cell lines both undergo morphological differentiation and, in some cases, respond by elevations in ChAT activity when treated with dbcAMP (Daniels and Hamprecht, 1974; Prasad and Kumar, 1974; Green and Tischler, 1976). Indeed, the dbcAMP-treated (1 mM, $2 \mathrm{~d}$ ) SN56.B5.G4 cells released $\mathrm{ACh}$, and this release more than

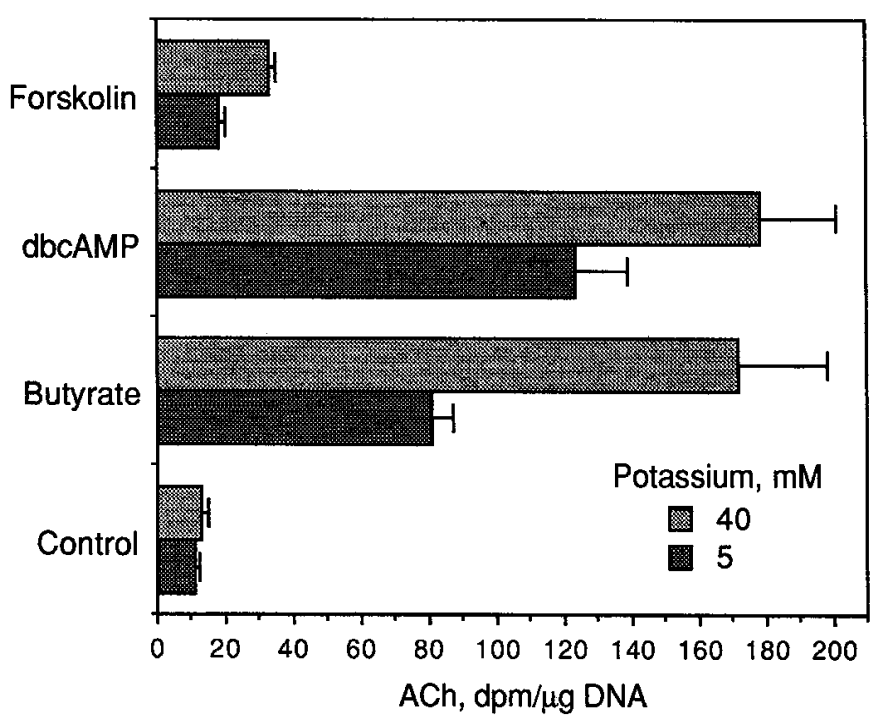

Figure 5. ${ }^{11} \mathrm{C}$-ACh release from SN56.B5.G4 cells. The cells were grown as described in Materials and Methods in DMEM containing 10\% FBS and $1 \mathrm{~mm}$ dbcAMP, $2 \mathrm{~mm}$ butyrate, or $10 \mu \mathrm{M}$ forskolin for $48 \mathrm{hr}$. They were washed with $2 \mathrm{ml}$ of $\mathrm{L}-15$ medium containing $15 \mu \mathrm{M}$ eserine and incubated for $180 \mathrm{~min}$ at $37^{\circ} \mathrm{C}$ in $1 \mathrm{ml}$ of the same medium containing $10 \mu \mathrm{M}{ }^{14} \mathrm{C}$-choline. The cells were then washed with $2 \mathrm{ml}$ of $\mathrm{L}-15$ medium and incubated for an additional $30 \mathrm{~min}$ in $0.7 \mathrm{ml}$ of physiological salt solution containing (in $\mathrm{mM}$ ) $\mathrm{NaCl}, 135 ; \mathrm{KCl}, 5 ; \mathrm{CaCl}_{2}, 1 ; \mathrm{MgCl}_{2}, 0.75$; glucose, 5; eserine, 0.015 ; and HF.PFS, 10; pH 7.4 (control) or elevated $(40 \mathrm{~mm})$ potassium concentrations (in the high-potassium medium sodium concentration was reduced to $100 \mathrm{~mm}$ ). ${ }^{14} \mathrm{C}$ - $\mathrm{ACh}$ released from the cells was purified by HPLC and its radioactivity determined. The data are means \pm SEM of four determinations. The data were analyzed by a two-way ANOVA. The effect of treatment and the effect of depolarization were statistically significant at $p<0.001$.

doubled in cells depolarized by high extracellular concentrations of potassium (Fig. 3). ACh release was also observed in cells treated with butyrate or forskolin. The permissive effects of these agents on ACh release in SN56.B5.G4 cells may be due to either differentiation of the excitable properties of cell membranes, including expression of specific ion channels, or differentiation of $\mathrm{ACh}$ release mechanisms such as vesicular storage of $\mathrm{ACh}$ or proteins involved in vesicular release.

The ability to release ACh in dbcAMP-trcatcd cclls accompanied neurite outgrowth (Fig. 1) and stimulation of ChAT activity and ACh synthesis (Fig. 2). The latter effect of dbcAMP was maximal after $2 \mathrm{~d}$ of treatment, suggesting that it was mediated by changes in ChAT gene expression, translation, or ChAT

Table 1. Effect of sodium on the accumulation of ${ }^{14} \mathrm{C}-\mathrm{ACh}$ in SN56.B5.G4 cells

\begin{tabular}{lll} 
& \multicolumn{2}{l}{ ACh } \\
\cline { 2 - 3 } Conditions & $1 \mu \mathrm{M}$ Choline & $5 \mu \mathrm{M}$ Choline \\
\hline Control (pmol/dish) & $4.1 \pm 0.6$ & $20.4 \pm 1.1$ \\
No sodium (pmol/dish) & $1.2 \pm 0.3$ & $12.0 \pm 0.6$ \\
No sodium (\% control) & 29 & 60 \\
Significance & $p<0.011$ & $p<0.003$
\end{tabular}

The cells were treated as described in Figure 6 . The physiological salt solution contained $135 \mathrm{~mm} \mathrm{NaCl}$ (Control) or $135 \mathrm{~mm} \mathrm{LiCl}$ (No sodium). The results are mcans \pm SEM of three determinations. Statistical significance of differences between means was determined by $t$ test. 


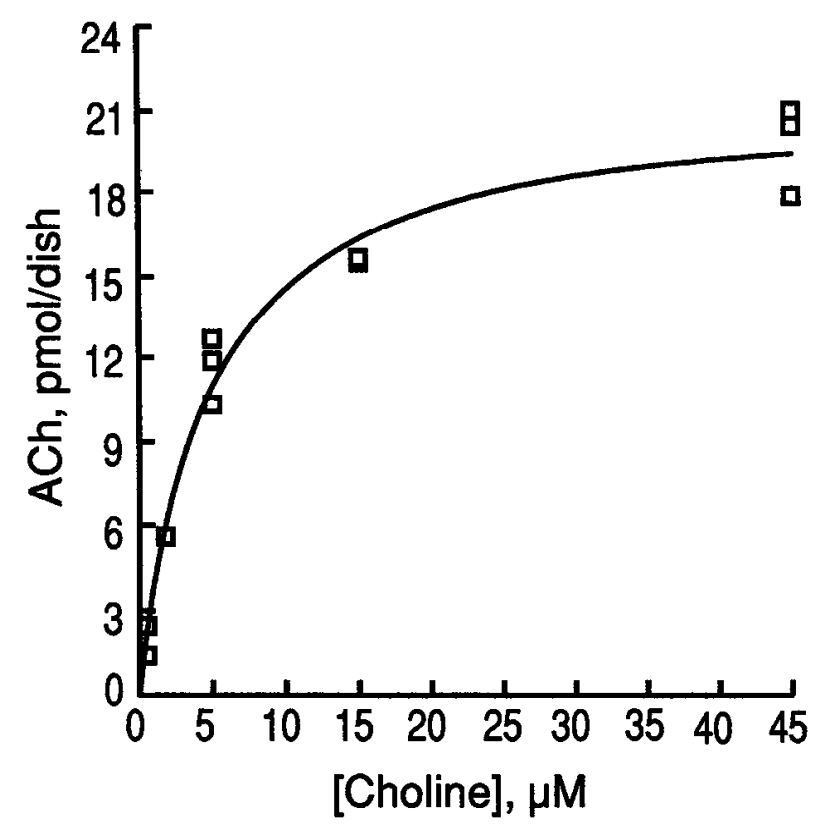

Figure 6. ${ }^{14} \mathrm{C}-\mathrm{ACh}$ accumulation in SN56.B5.G4 cells. SN56.B5.G4 cells were grown as described in Materials and Methods in $35 \mathrm{~mm}$ diameter culture dishes until approximatcly $50 \%$ confluent. The cells were washed with $1 \mathrm{ml}$ of physiological salt solution, and then $1 \mathrm{ml}$ of the same solution containing ${ }^{14} \mathrm{C}$-choline at various concentrations was added. The cells were incubated for $10 \mathrm{~min}$ at $37^{\circ} \mathrm{C}$ and then washed with $1 \mathrm{ml}$ of the same medium devoid of label. Choline metabolites were extracted and purified by HPLC, and their radioactivities were determined as described in Materials and Methods. The results were calculated using the specific radioactivity of the ${ }^{14} \mathrm{C}$-choline precursor. The data are results from triplicate determinations. A rectangular hyperbola was fit to the data according to the Michaelis equation. Correlation coefficient of this regression was $r^{2}=0.994$.

protein turnover rather than by a direct enzyme activation. However, it is also possible that ChAT was activated by a factor (perhaps an enzyme that modifies ChAT) whose expression required $2 \mathrm{~d}$ to develop fully. If these effects of dbcAMP were due to the cAMP moiety of this molecule, then in cells treated with forskolin, which should activate the cellular adenylate cyclase and thus increase the intracellular cAMP concentration, similar results should be observed. Consistent with this prediction, the forskolin-treated (10 $\mu \mathrm{M}, 2 \mathrm{~d})$ cells developed neurites and had ChAT activity and ACh content similar to that of dbcAMPtreated cells, and higher than the controls (Fig. 2). The molecule of dbcAMP permeates into cells due to its butyrate moieties. Hydrolysis of dbcAMP yields free butyrate, which has been shown to stimulate ChAT activity in neuroblastoma cells (Prasad and Kumar, 1974; Szutowicz et al., 1983; Casper and Davies, 1989). A similar effect of butyrate ( $2 \mathrm{mM}, 2 \mathrm{~d}$ ) was observed here (Fig. 2). In addition, butyrate increased ACh content of SN56.B5.G4 cells (Fig. 2), but no neurite extension was seen in such cells (Fig. 1C).

Each of the three treatments used (dbcAMP, forskolin, butyrate) had a characteristic effect on SN56.B5.G4 cells. Forskolin and dbcAMP caused neurite outgrowth, suggesting that elevated intracellular cAMP concentration was involved in the morphological differentiation of these cells. Forskolin- and dbcAMPtreated cells exhibited high ChAT activity and contained 70$80 \%$ more $\mathrm{ACh}$ than did the controls. However, the ${ }^{14} \mathrm{C}$ - ACh release in the forskolin-treated cells was only $15-18 \%$ of that observed in cells grown in the presence of dbcAMP (Fig. 5). In butyrate-treated cells, ChAT activity was stimulated, ACh content was increased, and $\mathrm{ACh}$ release was high, but no neurite extension occurred, indicating that morphological differentiation was not necessarily associated with the enhancement of the cholinergic phenotype.

Taken together, the data presented above show that SN56.B5.G4 cells are characterized by (1) ACh synthesis and storage, (2) SDHACU, and (3) depolarization-evoked $\mathrm{ACh}$ release. These properties satisfy the criteria indicative of the cholinergic phenotype. Treatment with dbcAMP causes both morphological and neurochemical differentiation, stimulates $\mathrm{ACh}$ synthesis, and allows the cells to release $\mathrm{ACh}$ upon depolarization. It will be important to determine whether physiologically relevant agents alter the cholinergic phenotype. In this regard, it is worth noting that IL-3 (Kamegai et al., 1990b) and GMCSF (Kamegai et al., 1990a) have been reported to stimulate ChAT activity in septal neurons as well as in one of our cell lines (SN6.10.2.2) derived from embryonic septum, indicating that these cells will be useful as models to study the molecular mechanisms of action of these and other growth and differentiating factors on the cholinergic phenotype.

\section{References}

Adler JE, Schleifer LS, Black IB (1989) Partial purification and characterization of a membrane-derived factor regulating neurotransmitter phenotypic expression. Proc Natl Acad Sci USA 86:1080-1083.

Blusztajn JK, Wurtman RJ (1983) Choline and cholinergic neurons. Science 221:614-620.

Bostwick JR, Landers DW, Crawford G, Lau K, Appel SH (1989) Purification and characterization of a central cholinergic enhancing factor from rat brain: its identity as phosphoethanolamine. J Neurochem 53:448-458.

Casper D, Davies P (1989) Stimulation of choline acetyltransferase activity by retinoic acid and sodium butyrate in a cultured human neuroblastoma. Brain Res 478:74-84.

Cohen EL, Wurtman RJ (1976) Brain acetylcholine: control by dietary choline. Science 191:561-562.

Daniels MP, Hamprecht B (1974) The ultrastructure of neuroblastoma glioma somatic cell hybrids. Expression of neuronal characteristics stimulated by dibutyryl adenosine $3^{\prime}, 5^{\prime}$ cyclic monophosphate. J Cell Biol 63:691-699.

Fonnum F (1975) A rapid radiochemical method for the determination of choline acetyltransferase. J Neurochem 24:407-409.

Fukada K (1985) Purification and partial characterization of a cholinergic neuronal differentiation factor. Proc Natl Acad Sci USA 82: 8795-8799.

Green LA, Tischler AS (1976) Establishment of noradrenergic clonal line of rat adrenal pheochromocytoma cells which respond to NGF. Proc Natl Acad Sci USA 73:2424-2428.

Hammond DN, Lee HJ, Tonsgard JH, Wainer BH (1990) Development and characterization of clonal cell lines derived from septal cholinergic neurons. Brain Res 512:190-200.

Hefti F, Hartikka J, Eckenstein F, Gnahn H, Heumann R, Schwab ME (1985) Nerve growth factor increases choline acetyltransferase but not survival or fiber outgrowth of cultured fetal septal cholinergic neurons. Neuroscience 14:55-68.

Kamegai M, Konishi Y, Tabira T (1990a) Trophic effect of granulocyte-macrophage colony-stimulating factor on central cholinergic neurons in vitro. Brain Res 532:323-325.

Kamegai M, Niijima K, Kunishita T, Nishizawa M, Ogawa M, Araki M, Ueki A, Konishi Y, Tabira T (1990b) Interleukin 3 as a trophic factor for central cholinergic neurons in vitro and in vivo. Neuron 4: $429-436$.

Kato AC, Lefresne P, Berwald-Netter Y, Bojouan JC, Glowinski J, Gross F (1977) Choline stimulates the synthesis of acetylcholine from acetate and the accumulation of acetate in a cholinergic neuroblastoma clone. Biochem Biophys Res Commun 78:350-356.

Keller F, Rimvall K, Waser PG (1987) Choline and acetylcholine 
metabolism in slice cultures of the newborn rat septum. Brain Res 405:305-312.

Labarca C, Paigen K (1980) A simple, rapid, and sensitive DNA assay procedure. Anal Biochem 102:344-352.

Lanks K, Somers L, Papirmeister B, Yamamura H (1974) Choline transport by neuroblastoma cells in tissue culture. Nature 252:476478.

Lee HJ, Hammond DN, Large TH, Wainer BH (1990) Immortalized young adult neurons from the septal region: generation and characterization. Dev Brain Res 52:219-228.

Liscovitch M, Freese A, Blusztajn JK, Wurtman RJ (1985) Highperformance liquid chromatography of water-soluble choline metabolites. Anal Biochem 151:182-187.

McGee R Jr (1980) Choline uptake by the neuroblastoma $\times$ glioma hybrid, NG 108-15. J Neurochem 35:829-837.

McManaman JL, Crawford FG, Stewart SS, Appel SH (1988) Purification of a skeletal muscle polypeptide which stimulates choline acetyltransferase activity in cultured spinal cord neurons. J Biol Chem 263:5890-5897.

Melega WP, Howard BD (1981) Choline and acetylcholine metabolism in PC12 secretory cells. Biochemistry 20:4477-4483.

Morel N, Israel M, Manaranche R, Mastour-Frachon P (1977) Isolation of pure cholinergic nerve endings from Torpedo electric organ. J Cell Biol 75:43-55.

Parsons SM, Bahr BA, Gracz LM, Kaufman R, Kornreich WD, Nilsson L, Rogers GA (1987) Acetylcholine transport: fundamental properties and effects of pharmacologic agents. Ann NY Acad Sci 493 220-233.

Potter PE, Meek JL, Neff NH (1983) Acetylcholine and choline in neuronal tissue measured by HPLC with electrochemical detection. J Neurochem 41:188-194.

Prasad KN, Kumar S (1974) Cyclic AMP and the differentiation of neuroblastoma cells in culture. In: Control of proliferation in animal cells (Clarkson B, Baserga R, eds), pp 581-594. Cold Spring Harbor, NY: Cold Spring Harbor Laboratory.

Rao MS, Landis SC (1990) Characterization of a target-derived neuronal cholinergic differentiation factor. Neuron 5:899-910.

Richardson UI, Liscovitch M, Blusztajn JK (1989) Acetylcholine synthesis and secretion by I.A-N-2 human neuroblastoma cells. Brain Res 476:323-331.

Saadat S, Sendtner M, Rohrer H (1989) Ciliary neurotrophic factor induces cholinergic differentiation of rat sympathetic neurons in culture. J Cell Biol 108:1807-1816.

Shelton DL, Nadler JV, Cotman CW (1979) Development of high affinity choline uptake and associated acetylcholine synthesis in the rat fascia dentata. Brain Res 163:263-275.

Smith PK, Krohn RI, Hermanson GT, Mallia AK, Gartner FH, Provenzano MD, Fujimoto EK, Goeke NM, Olson BJ, Klenk DC (1985) Measurement of protein using bicinchoninic acid. Anal Biochem 150: 76-85 [published erratum appears in Anal Biochem 163:279].

Suszkiw JB, Pilar G (1976) Selective localization of a high affinity choline uptake system and its role in $\mathrm{ACh}$ formation in cholinergic nerve terminals. J Neurochem 26:1133-1138.

Szutowicz A, Morrison MR, Srere PA (1983) The enzymes of acetylCoA metabolism in differentiating cholinergic (S-20) and noncholinergic (NIE-115) neuroblastoma cells. J Neurochem 40:1664-1670.

Vaca K, Stewart SS, Appel SH (1989) Identification of basic fibroblast growth factor as a cholinergic growth factor from human muscle. J Neurosci Res 23:55-63.

Yamamori T, Fukada K, Aebersold R, Korsching S, Fann M-J, Patterson PH (1989) The cholinergic neuronal differentiation factor from heart cells is identical to leukemia inhibitory factor. Science 246: $1412-1416$ 